\title{
CARRYOVER OF IMAZETHAPYR + IMAZAPIC ON RYEGRASS AND Non-tolerant Rice as Affected by Thickness of SoIl Profile ${ }^{1}$
}

\author{
Residual de Imazethapyr + Imazapic sobre Azevém e Arroz Irrigado, em Função da Espessura do \\ Perfil do Solo
}

BUNDT, A.D.C. ${ }^{2}$, AVILA, L.A. ${ }^{2}$, AGOSTINETTO, D. ${ }^{2}$, NOHATTO, M.A. ${ }^{2}$, and VARGAS, H.C. ${ }^{2}$

\begin{abstract}
Herbicides used in Clearfield ${ }^{\circledR}$ rice system may persist in the environment, damaging non-tolerant crops sown in succession and/or rotation. These damages vary according to soil characteristics, climate and soil management. The thickness of the soil profile may affect carryover effect; deeper soils may allow these molecules to leach, reaching areas below the roots absorption zone. The aim of this study was to evaluate the effect of the thickness of soil profile in the carryover of imazethapyr + imazapic on ryegrass and nontolerant rice, sown in succession and rotation to rice, respectively. Lysimeters of different thicknesses $(15,20,30,40,50$ and $65 \mathrm{~cm})$ were constructed, where $1 \mathrm{~L} \mathrm{ha}^{-1}$ of the imazethapyr + imazapic formulated mixture was applied in tolerant rice. Firstly, imidazolinone-tolerant rice was planted, followed by ryegrass and non-tolerant rice in succession and rotation, respectively. Herbicide injury, height reduction and dry weight of non-tolerant species were assessed. There was no visual symptoms of herbicide injury on ryegrass sown 128 days after the herbicide application; however it causes dry weight mass reduction of plants. The herbicides persist in the soil and cause injury in non-tolerant rice, sown 280 days after application, and the deeper the soil profile, the lower the herbicides injury on irrigated rice.
\end{abstract}

Keywords: degradation, imidazolinone, Lolium multiflorum, leaching, Oryza sativa.

\begin{abstract}
RESUMO - Os herbicidas usados na cultura do arroz Clearfield ${ }^{\mathbb{}}$ podem persistir no ambiente $e$ causar danos às culturas não tolerantes cultivadas em sucessão e/ ou rotação ao arroz irrigado. Esses danos são variáveis, dependendo das características do solo, clima e manejo. A espessura do perfil do solo pode potencializar o efeito residual desses herbicidas, visto que solos mais profundos permitem que essas moléculas percolem até regiões fora da zona de absorção das raizes das plantas. Em vista do exposto, o objetivo deste trabalho foi avaliar o efeito da espessura do perfil do solo na atividade residual da mistura herbicida imazethapyr + imazapic sobre azevém e arroz irrigado não tolerantes, semeados em sucessão e rotação ao arroz irrigado, respectivamente. Para isso, foram construidos lisimetros com diferentes espessuras (15, 20, 30, 40, 50 e $65 \mathrm{~cm})$, onde foi aplicado o equivalente a $1 \mathrm{~L} \mathrm{ha} \mathrm{h}^{-1}$ da mistura formulada por imazethapyr + imazapic. Primeiramente, foi semeado arroz irrigado tolerante a imidazolinonas, seguido por azevém e arroz irrigado não tolerantes, em sucessão e rotação, respectivamente. Foram avaliadas a fitointoxicação e a redução de estatura e massa da matéria seca das espécies não tolerantes. A mistura formulada por imazethapyr imazapic não resulta em fitotoxicidade visual ao azevém semeado 128 dias após a aplicação do herbicida, porém causa redução na massa da matéria seca das plantas. Os mesmos herbicidas persistem no solo e causam fitotoxicidade no arroz não tolerante semeado 280 dias após a aplicação; quanto mais profundo o perfil do solo, menor será a fitotoxicidade dos herbicidas no arroz irrigado.
\end{abstract}

Palavras-chave: degradação, imidazolinona, Lolium multiflorum, lixiviação, Oryza sativa.

Recebido para publicação em 19.6.2014 e aprovado em 18.9.2014.

Universidade Federal de Pelotas, Pelotas-RS, Brasil, <laavilabr@gmail.com>.

Planta Daninha, Viçosa-MG, v. 33, n. 2, p. 357-364, 2015 


\section{INTRODUCTION}

The Rice Clearfield $\AA$ system is the use of tolerant cultivar with the application of imidazolinone herbicides Only ${ }^{\circledR}$ (imazethapyr + imazapic, $75+25$ g i.a. $\mathrm{L}^{-1}$, respectively) and $\mathrm{Kifix}^{\circledR}$ (imazapic + imazapyr, $525+175$ g i.a. $\mathrm{kg}^{-1}$, respectively). These herbicides inhibit the acetolactate synthase enzyme (ALS). In rice paddy fields, these herbicides are persistent in soil. This persistence is due to the limited anaerobic soil degradation (Mangels, 1991; Kraemer et al., 2009), common condition during rice cultivation, and during the off season in rainy years. The presence of these herbicides in the soil may cause problems to non-tolerant crops, grown in succession or in rotation. Damages to non-tolerant rice vary with environmental conditions and crop management, injury can vary from reduction in plant stand (Villa et al., 2006) and reduction in yield up to 69\% (Zhang et al., 2000).

Studies show that the main form of imidazolinone dissipation in soil is through microbial degradation (Loux et al., 1989; Flint \& Witt, 1997), however, for this to occur, the environmental conditions must be favorable to the development of degrading microorganisms. Microbial degradation may occur under aerobic conditions only, such as imazapic (Mangels, 1991), or aerobic and anaerobic conditions, as in the case of imazapyr (Wang et al., 2006).

Another important characteristic of these herbicides is its mobility in soil. Studies show that imidazolinone have little horizontal mobility (Tu et al., 2004) however 80 to 90\% of the herbicide applied may concentrate vertically in the $10-20 \mathrm{~cm}$ layer of the soil profile, and remain there for long periods (Loux \& Reese, 1993; Monquero et al., 2008; Kraemer et al., 2009). There are several signs of imazapic and imazethapyr accumulation in the soil, specifically in fields with two or more consecutive use of the Clearfield system or areas with over dosage (Ball et al., 2003; Kraemer et al., 2009; Pinto et al., 2009a,b). This accumulation is due to these herbicides limited degradation under conditions of low oxygen supply, as well as low microbial activity in deeper soil zones.
Herbicide leaching could affect the damage caused to non-tolerant crops, because it can moves to areas below the roots absorption zone. However, these herbicides may cross the soil impermeable layer and reach groundwater sources (Silva et al., 2011). This question is very important, since water sources, besides serving as rivers recharge, are also a source of drinking water for human consumption.

Another extremely important issue is that the imidazolinone mobility in soil is not limited to the downward vertical movement. These herbicides can move upwardly along the soil profile, according to the water table oscillations (Van Wyk \& Reinahardt, 2001; Firmino et al., 2008; Bundt, 2013). Therefore, the herbicide located in greater depth may return to the soil surface, during the period after rice harvest, causing damage to crops sown in succession and/ or rotation.

Ryegrass (Lolium multiflorum) is one of the most important winter pasture in southern Brazil grown in rotation with rice. Nevertheless, it may be adversely be affected by the herbicide residues in soil. Studies show that ryegrass seeds have reduced growth as well as dry matter when grown in imidazolinone treated areas (Pinto et al., 2009a).

Given the heterogeneity of soils, it is necessary to understand the influence of the soil profile thickness in leaching and the carryover of the herbicide imazethapyr + imazapic. This study's objective was to evaluate the effect of the soil profile thickness on carryover of imazethapyr + imazapic on ryegrass and non-tolerant rice, sown in succession and rotation, respectively.

\section{MATERIAL AND METHODS}

The experiment was carriedout under greenhouse conditions, using completely randomized design in a factorial arrangement, with four replications. Factor A consisted of different soil profile thickness $(15,20,30,40$, 50 and $65 \mathrm{~cm}$ ); and factor $B$ in the presence and absence (untreated check) of $1 \mathrm{~L} \mathrm{ha}^{-1}$ of imazethapyr + imazapic formulated mixture.

Lysimeters were constructed with a $20 \mathrm{~cm}$ diameter PVC pipe with different heights 
(corresponding to the soil profile thickness treatments) (Figure 1). The soil was collected from rice field. The soil is classified as Tipic Albaqualf, with the following characteristics: $\mathrm{pH}$ water $(1: 1)=5,1 ; \mathrm{CTC} \mathrm{pH} 7=5,4 \mathrm{cmol}_{\mathrm{c}} \mathrm{dm}^{-3}$; organic matter $=1,2 \%$; clay $=15 \%$; texture $=4$; $\mathrm{Ca}=1,8 \mathrm{cmol}_{\mathrm{c}} \mathrm{dm}^{-3} ; \mathrm{Mg}=1 \mathrm{cmol}_{\mathrm{c}} \mathrm{dm}^{-3}$; Al exchangeable $=0,2 \mathrm{cmol}_{\mathrm{c}} \mathrm{dm}^{-3} ; \mathrm{P}$ available $=4,3 \mathrm{mg} \mathrm{dm}^{-3}$; and $\mathrm{K}$ exchangeable $=30 \mathrm{mg} \mathrm{dm}^{-3}$. The soil was dried at room temperature, sieved and packed into the lysimeters.

The experiment was divided into three phases. Firstly, field conditions were simulated and before tolerant rice seeding herbicide was applied to soil. To avoid effects of borders of the lysimeters, herbicide were firstly applied in 250 grams of soil and blended. After a resting period of 24 hours, period required for the sorption equilibrium, the treated soil was transferred to the lysimeters, deposited as a thin layer on the surface.

Immediately after treated soil was transferred to the lysimeters, 15 seeds of rice cultivar IRGA $422 \mathrm{CL}$, tolerant to the imidozolinones herbicides, were sown at $1 \mathrm{~cm}$ depth. Shortly after the plants emergence, population was standardized to eight plants per experimental unit. Plants were irrigated daily until they reached the stage of four leaves. From this stage, they were flooded, and remained in a $10 \mathrm{~cm}$ water depth throughout

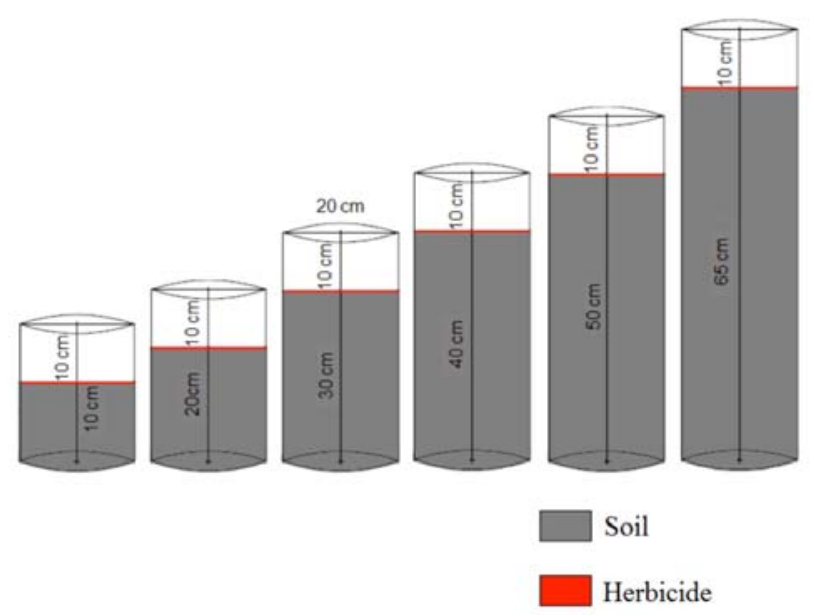

Figure 1 - Assembly arrangement of the experiment of imazapic and imazethapyr carryover to non-tolerant ryegrass and rice, with different soil profile thickness. the experimental period. At planting, it was applied the corresponding of $350 \mathrm{~kg} \mathrm{ha}^{-1}$ 5-22-22 (N-P-K). Nitrogen topdressing was applied as urea and split into two stages: $70 \mathrm{~kg}$ $\mathrm{N}$ in V4 stage, just before the flood, and $40 \mathrm{~kg}$ $\mathrm{N} \mathrm{ha}^{-1}$ at R0 stage (panicle initiation). This first stage of the experiment was conducted until the end of the growing season; at 109 days after the herbicide application (DAA), plants were cut at soil level, dried in oven with forced air circulation at $60^{\circ} \mathrm{C}$, and weighed to obtain the shoot dry weight.

At 128 DAA, the second phase of the experiment began. At this stage, 20 ryegrass seeds were sown in soil columns, where, after thinning, only eight plants per experimental unit have been preserved. At 30 days after ryegrass sowing, the topdressing nitrogen fertilization was performed, applying the equivalent of $100 \mathrm{~kg} \mathrm{~N}^{\mathrm{N}} \mathrm{ha}^{-1}$. Lysimeters were weighed weekly to establish the uniformity in the soil moisture content. It was assessed herbicide injury to ryegrass plants at 14,28 , 42, 56 and 70 days after emergence (DAE); and dry matter mass of shoots (g) according to the methodology described.

The third phase of the experiment consisted on the seeding of non-tolerant rice cultivar IRGA 417. Seeds were sown at 280 DAA; 15 seeds per lysimeter; after thinning, eight plants left. Flooding as well as fertilization management were identical to those described in the experiment's first stage. It was assessed herbicide injury to rice plants at $7,14,21$ and 28 DAE, dry mass (grams) and height $(\mathrm{cm})$ of plants' shoots at $32 \mathrm{DAE}$, according to methodology described earlyier.

Data were analyzed for compliance to the assumptions of the mathematical model and submitted to the analysis of variance and polynomial regression.

\section{RESULTS AND DISCUSSION}

No significant difference (ANOVA, F test, $p \leq 0.05$ ) was observed, among treatments for dry mass weight reduction of IRGA $422 \mathrm{CL}$ tolerant cultivar. However, a $4 \%$ average reduction of shoot dry weight was observed, when plants were grown in lysimeters that received the herbicide application (data not 
shown). This result is an expected result for this cultivar, as it can suffer damage due to the herbicide application in pre-emergence. Some Clearfield ${ }^{\mathrm{TM}}$ cultivars may show injury when imidazolinones herbicides are applied. Villa et al. (2006) found that high rates (greater than $1 \mathrm{~L} \mathrm{ha}^{-1}$ ) of the same herbicide used in this experiment, cause injury to the tolerant IRGA $422 \mathrm{CL}$ cultivar, applied in post-emergence, however grain yield was not affected.

For ryegrass, no visual injury symptoms were observed (data not shown). In contrast, a dry matter reduction in all soil profile thicknesses occurred (Figure 2), which shows the herbicide carryover to ryegrass plants. These results are similar to those reported by Pinto et al. (2009a), who found that imazethapyr + imazapic, applied at a $1.0 \mathrm{~L} \mathrm{ha}^{-1}$ in post-emergence irrigated rice, remains active in the soil to significantly reduce the plant's aboveground dry height, its biological yield and the germination potential of ryegrass seed sown in rotation, after a year of CL rice cultivation. In contrast, Grohs et al. (2008) showed no carryover effect on ryegrass emergence, and shoot dry weight. This divergence between authors is probably due to the soil physic-chemical characteristics as well as moisture conditions when ryegrass was planted. The oboveground dry weight reduction varied widely within each treatment. These results are acceptable, since the soil moisture is a very important factor in the bioavailability of imidazolinone herbicides (Baughman \& Shaw, 1996; Avila et al., 2005). During the second phase of the experiment, a great variability of soil moisture in the lysimeters may have occurred, once this factor was controlled by weighing experimental units weekly only, with water additional replacement over time. However, this is not an accurate controlling soil moisture method, once it cannot estimate the water volume along the lysimeter.

Another important factor that should be noted is the fact that imidazolinone are weak acid molecules herbicides, for this reason its availability in soil is influenced by soil $\mathrm{pH}$ (Loux \& Reese, 1993). It is known that its adsorption determines how much of the herbicide will be sorbed to the soil matrix and

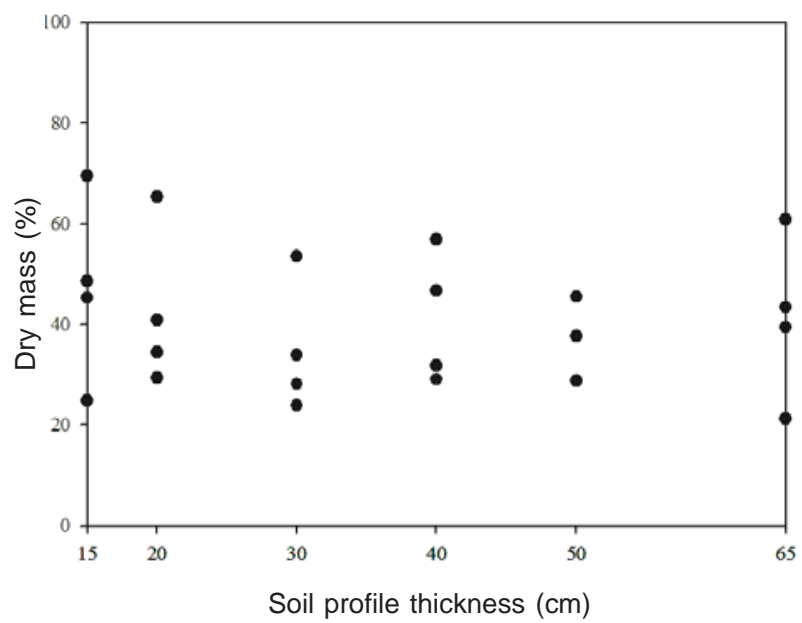

Figure 2 - Aboveground shoot dry weight reduction percentage of the untread check, observed in ryegrass, assessed at 128 days after herbicide application, in response to soil profile thickness.

how much is available in the solution. For weak acid herbicides low soil $\mathrm{pH}$ provides higher adsorption (Bresnaham et al., 2000; Madani et al. 2003; Oliveira et al, 2004), which are less available to plants. The rice soils of Rio Grande do Sul state are predominantly acidic in its natural condition, and approximately $50 \%$ of them have $\mathrm{pH}$ lower than 5 (Anghinoni et al., 2004). Under these conditions, imazethapyr and imazapic herbicides have a high probability of remaining sorbed in the soil, increasing its persistence carryover effect. The soil used in the experiment had $\mathrm{pH} 5.1$, which probably provided higher adsorption of herbicide molecules in the soil colloids, once this remained more on the associated form and therefore, less soluble and less available for absorption by plants root.

There was injury in rice sown 280 days after the herbicide treatment in all soil profile depths (Figure 3). Herbicide injury in early development stages of non-tolerant rice, planted in rotation to the Clearfield system, has been demonstrated in other studies, such as Massoni's et al. (2007) and Marchezan's et al. (2010), who reported the same herbicide carryover on non-tolerant rice 358 days after application. Other authors also show that this herbicide remains in the soil, and may suppress the seedlings development in non-tolerant cultivars planted in rotation (Noldin et al., 2005; Villa et al., 2006; Kraemer et al., 2009). 


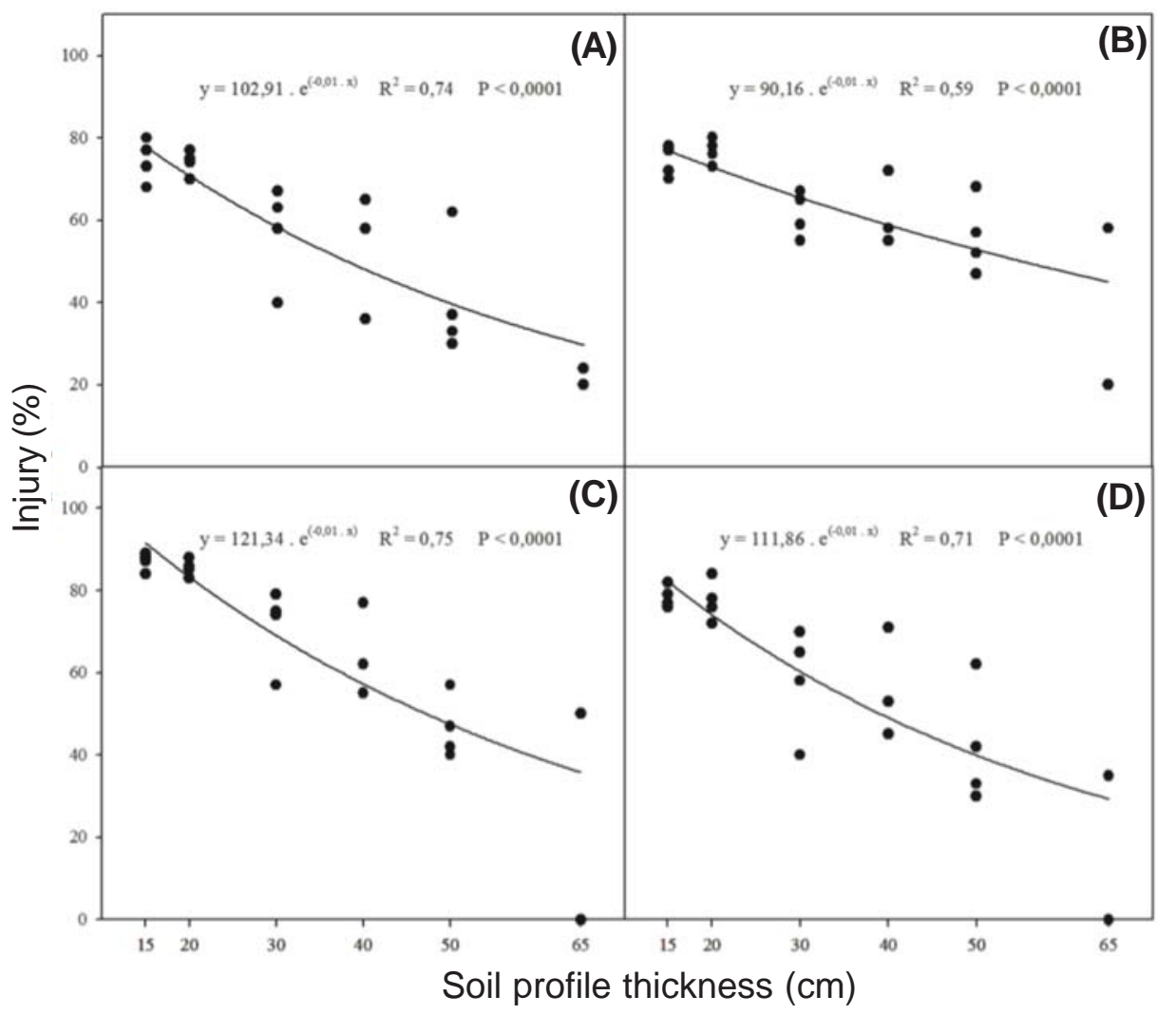

Figure 3 - Non-tolerant (IRGA 417) rice injury observed at 7 (A), 14 (B) 21 (C) 28 (D) days after seedling emergence, in response to soil profile thickness.

Results of the experiment's show that there was significant difference (ANOVA, F-test, $\mathrm{p} \leq 0.05$ ) between the soil profile thicknesses; the deeper the soil is, the lower the injury observed in the plants. This result shows that in deeper soils the herbicide carryover is lower compared to shallower soils. This behavior can be explained by the herbicide leaching in the lysimeter, reaching greater depths in those treatments with thicker profile; however in the shallower ones, the impervious layer physical barrier has limited the herbicide leaching, promoting a higher herbicide accumulation near the soil surface. When the herbicide leaches to greater depths, there is a relative positioning selectivity (Bundt et al., 2010). When the herbicide is deeper in soil profile, seedlings roots absorbs less herbicide, once it is not located in the higher absorption zone of most plants root. However, with the plants growth, the root system at some point reaches the herbicide location zone, causing its absorption.
As the root growth is accompanied by an advanced stage of plants development, the herbicide absorption does not provide significant injury, as the rice plants show an increased tolerance to herbicide effect. This tolerance may be related to the plant mass increase; and /or to dilution and; and/or to the increase on detoxification ability.

Importantly, the leaching phenomenon, while it may be considered a selectivity factor, can also be the cause of environmental contamination. When the herbicide is located in greater depth of the soil, it can contaminate ground and surface waters. Several studies have shown this type of contamination. In the US, 16 herbicides active ingredients from sulfonylurea, sulfonamide and imidazolinone groups, were found in samples collected on surface and groundwater (Battaglin et al., 2000), and the herbicide most frequently found was imazethapyr, detected in $71 \%$ of samples; imazapyr traces were also found in ground 
waters (Börjesson et al., 2004; Silva et al., 2009, 2011).

Reduction on aboveground dry weight of non-tolerant rice (Figure 4) was lower in deeper soil profile treatments. Similar results were observed by Kraemer et al. (2009). The rice plants height also showed similar behavior to injury and dry matter mass (Figure 5). A lower reduction in height with increasing depth of the soil profile was observed, which shows the hypothesis that in deeper soils the herbicide carryover effect is minor.

The difference response between ryegrass and non-tolerant rice may have been due to the crops management system. Ryegrass is cultivated without flooding, which means that $\mathrm{pH}$ remains under normal conditions, i.e. close to 5.0. At the moment the irrigated rice is implanted and flooding is established, the soil lack of oxygen provides a reducing environment, resulting in natural soil $\mathrm{pH}$ increase, reaching levels close to neutrality. Under these conditions, weak acid molecule herbicides tend to become available again in the soil solution at levels that can become harmful to non-tolerant rice varieties. It is worth mentioning that natural $\mathrm{pH}$ increase has a significant effect on the herbicide bioavailability to plants only after two weeks of soil flooding. The herbicide injury first symptoms are due to its immediate availability following soil flooding, because it becomes

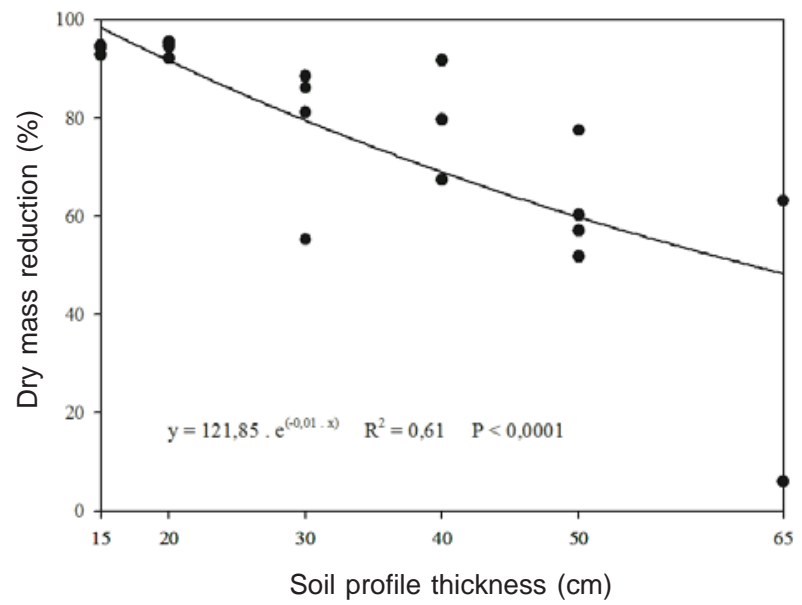

Figure 4 - Non-tolerant rice (IRGA 417) shoot dry weight reduction (percentage of untreated check) assessed at 28 days after seedling emergence, in response to soil profile thickness. more soluble with increase in soil water content (Avila et al., 2005), due to the molecule characteristic of being highly soluble in water (Senseman, 2007); as well as due to the herbicide molecules and water competition for the soil adsorption sites. This explains the injury symptoms observed in ryegrass grow in rainy winters, once the water excess increase herbicide availablility (Marchezan et al., 2009).

There are evidences that the management practices such as winter soil drainage management, which stimulate the herbicides degradation in the soil during the rice off-season, may reduce herbicides persistence in soil, minimizing damage to subsequent crops. Biological processes could be influenced by moisture, temperature and aeration, which are environmental factors provided by the soil tillage practices (Soon \& Arshad, 2005; Perez et al, 2005), that may increase up to $57 \%$ the microbial activity (Franchini et al., 2007), providing therefore a more rapid degradation of these herbicides.

In summary, the imazethapyr + imazapic herbicide does not cause injury to ryegrass, sown 128 days after the herbicide application, nevertheless causes a reduction in the plants aboveground shoot dry weight. They can remain in the soil and cause injury to nontolerance rice, seeded 280 days after application; the deeper the soil profile is, the lower the herbicide injury in irrigated rice.

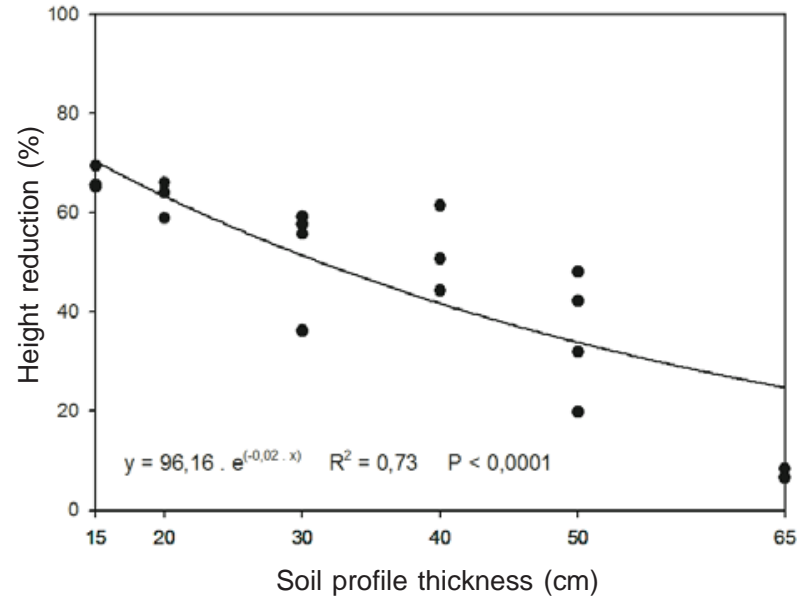

Figure 5 - Plant height reduction (\% of untrated check) observed in non-tolerant irrigated rice IRGA 417, assessed at 28 days after seedling emergence, in response to soil profile thickness. 


\section{LITERATURE CITED}

ANGHINONI, I. Fertilidade dos solos cultivados com arroz irrigado no Rio Grande do Sul. Cachoeirinha: IRGA, 2004. 52 p. (Boletim Técnico, 1).

AVILA, L. A. et al. Efeito da umidade do solo na sorção e disponibilidade de imazetapir em três solos. In: CONGRESSO BRASILEIRO DE ARROZ IRRIGADO, 4; REUNIÃO DA CULTURA DO ARROZ IRRIGADO, 26., 2005, Santa Maria. Anais... Santa Maria: Universidade Federal de Santa Maria, 2005. p. 190-193.

BALL, D. A.; YENISH, J. P.; ALBY, T. Effect of imazanox soil persistence on dryland rotational crops. Weed Technol., v. 17, n. 1, p. 161-165, 2003.

BATTAGLIN, W. A. et al. Occurrence of sulfonylurea, sulphonamide, imidazolinone, and other herbicides in rivers, reservoirs and ground water in the Midwestern UNITED STATES, 1998. Sci. Total Environ., v. 248, n. 2-3, p. 123-133, 2000.

BAUGHMAN, T. A.; SHAW, D. R. Effect of wetting/drying cycles on dissipation patterns of bioavailable imazaquin. Weed Sci., v. 44, n. 2, p. 380-382, 1996.

BÖRJESSON, E.; TORSTENSSON, L.; TENSTRÖM. J. The fate of imazapyr in a Swedish railway embankment. Pest Manag. Sci., v. 60, n. 6, p. 544-549, 2004.

BRESNAHAM, G. A. et al. Influence of soil pH-sorption interactions on imazethapyr carryover. Weed Sci., v. 48, n. 5, p. 1929-1934, 2000.

BUNDT, A. D. C. et al. Profundidade de localização do herbicida imazetapir + imazapique no solo sobre a fitotoxicidade em de plantas de arroz não resistente. Ci. Rural, v. 40, n. 9, p. 1867-1873, 2010.

BUNDT, A. D. C. et al. Transporte ascendente da mistura formulada de imazethapyr e imazapic em resposta à profundidade do lençol freático. Ci. Rural, v. 43, n. 9, p. 1597-1604, 2013.

FIRMINO, L. E. et al. Movimento do herbicida imazapyr no perfil de solos tropicais. Planta Daninha, v. 26, n. 1, p. 223-230, 2008.

FLINT, J. L.; WITT, W. W. Microbial degradation of imazaquin and imazethapyr. Weed Sci., v. 45, n. 4, p. 586-591, 1997.

FRANCHINI, J. C. et al. Microbiological parameters as indicators of soil quality under various soil management and crop rotation systems in southern Brazil. Soil \& Tillage Res., v. 92, n. 1, p. 18-29, 2007.
GROHS, M. et al. Residual da mistura formulada dos herbicidas imazethapyr e imazapic em solo de várzea sobre azevém (Lolium multiflorum Lam.) cultivado em sucessão ao arroz tolerante. Ci. Rural, v. 38, n. 6, p. 1754-1757, 2008.

LOUX, M. M.; LIEBL, R. A.; SLIFE, F. W. Adsorption of imazaquin and imazethapyr on soils, sediments and selected adsorbants. Weed Sci., v. 37, n. 5, p. 712-718, 1989.

LOUX, M. M.; REESE, K. D. Effect of soil pH on adsorption and persistence of imazaquin. Weed Sci., v. 40, n. 3, p. 490-496, 1993.

KRAEMER, A. F. et al. Persistência dos herbicidas imazethapyr e imazapic em solo de várzea sob diferentes sistemas de manejo. Planta Daninha, v. 27, n. 3, p. 581-588, 2009.

MADANI, M. E. et al. pH effect and kinetic studies of the binding behaviour of imazethapyr herbicide on some Moroccan soils. Fresenius Environ. Bulletin., v. 1, n. 9, p. 1114-1119, 2003.

MARCHEZAN, M. et al. Fitotoxicidade da mistura formulada de imazethapyr e imazapic sobre o azevém em função do teor de umidade do solo. In: CONGRESSO BRASILEIRO DE ARROZ IRRIGADO, 6., 2009, Porto Alegre. Anais... Porto Alegre: 2009.

MARCHEZAN, E. et al. Carryover of imazethapyr and imazapic to nontolerant rice. Weed Technol., v. 24, n. 1, p. 6-10, 2010.

MANGELS, G. Behavior of the imidazolinone herbicides in soil: a review of the literature. In: SHANER, D. L.; O’CONNOR, S. L. (Ed.). The imidazolinone herbicides. Boca Raton: CRC Press, 1991. p. 191-209.

MASSONI, P. F. S. et al. Controle de arroz vermelho em arroz tolerante a Imidazolinonas e o residual em genótipo de arroz não tolerante. In: CONGRESSO BRASILEIRO DE ARROZ IRRIGADO, 5., 2007, Pelotas. Anais... Pelotas: SOSBAI, 2007. v. 2. p. 230-233.

MONQUERO, P. A. et al. Potencial de lixiviação de herbicidas no solo submetidos a diferentes simulações de precipitação. Planta Daninha, v. 26, n. 2, p. 403-409, 2008.

NOLDIN, J. A. et al. Residual do herbicida Only em sistema de cultivo pré-germinado. In: CONGRESSO BRASILEIRO DE ARROZ IRRIGADO, 4., REUNIÃO DA CULTURA DO ARROZ IRRIGADO, 26., 2005, Santa Maria. Anais... Santa Maria: Universidade Federal de Santa Maria, 2005. p. 262-263. 
OLIVEIRA, M. F. et al. Sorção do herbicida imazaquin em Latossolo sob plantio direto e convencional. Pesq. Agropec. Bras., v. 39, n. 8, p. 787-793, 2004.

PINTO, J. J. O. et al. Atividade residual de (imazethapyr+imazapic) sobre azevém anual (Lolium multiflorum), semeado em sucessão ao arroz irrigado, Sistema Clearfield ${ }^{\circledR}$. Planta Daninha, v. 27, n. 3, p. 609-619, 2009a.

PINTO, J. J. O. et al. Atividade residual de (Imazethapyr+Imazapic) para sorgo granífero (Sorghum bicolor) semeado em rotação com o arroz irrigado.

Planta Daninha, v. 27, p. 1015-1024, 2009b. (Número Especial).

SILVA, D. R. O. et al. Monitoramento de agrotóxicos em águas superficiais de regiões orizícolas no sul do Brasil. Ci. Rural, v. 39, n. 9, p. 2383-2389, 2009.

PEREZ, K. S. S.; RAMOS, M. L. G.; McMANUS, C. Nitrogênio da biomassa microbiana em solo cultivado com soja, sob diferentes sistemas de manejo, nos Cerrados. Pesq. Agropec. Bras., v. 40, n. 2, p. 137-144, 2005.

SENSEMAN, S. A. et al. Herbicide handbook. Lawrence: Weed Science Society of America, 2007. 458 p.
SILVA, D. R. O. et al. Ocorrência de agrotóxicos em águas subterrâneas de áreas adjacentes a lavouras de arroz irrigado. Química Nova, v. 34, n. 5, p. 748-752, 2011.

SOON, Y. K.; ARSHAD, M. A. Tillage and liming effects on crop and labile soil nitrogen in an acid soil. Soil Tillage Research, v. 80, n. 1, p. 23-33, 2005.

TU, M. et al. Imazapic. In: TU, M. Weed control methods handbook. London: Academic, 2004. p. 1-7.

VANWYK, L. J.; REINHARDT, C. F. A bioassay technique detects imazethapyr leaching and liming-dependent activity. Weed Technol., v. 15, n. 1, p. 1-6, 2001.

VILLA, S. C. C. et al. Arroz tolerante a imidazolinona: controle do arroz vermelho, fluxo gênico e efeito residual do herbicida a culturas sucessoras não tolerantes.

Planta Daninha, v. 24, n. 4, p. 761-768, 2006.

WANG, X.; WANG, H.; FAN, D. Degradation and metabolism of imazapyr in soils under aerobic and anaerobic conditions. Int. J. Environ. Anal. Chemistry, v. 86, n. 8, p. 541-551, 2006.

ZHANG, W.; WEBSTER, E. P.; BRAVERMAN, M. P. Effect of rotational crop herbicides on water- and dry-seeded Oryza sativa. Weed Sci., v. 48, n. 6, p. 340-345, 2000. 